\title{
"Clean-up consultant to aisle 69 please"
}

\author{
Tess Bootbury
}

GPs don't moan, they simply get it off their chest. Well, thanks to the NHS Modernisation Plan - the stealth one, that is - I'm apparently going to have one less thing to moan about, sorry, get off my chest. That is, the lack of time to do the weekly shop. I'm now going to be able to practise what I preach by eating a variety of low-fat, fibre-rich, lower-salt, trans-free, added vitamins and minerals, pomegranate-enriched, heart, brain and bowel healthy foods instead of whatever's left after the drug rep's visit. Whoopee! You see, it looks like our new and improved practice is going to be the latest addition to our local supermarket.

Yes, our practice has decided that using the combined capital from re-mortgaging our homes, QOF bonuses and children's school fee funds (and their piggy banks) to build a brand new super-surgery that can never be used for anything other than health services (and consequently means we'd never enjoy the golden egg of the saleable four-storey townhouse that cost-rent schemes used to lay at a GP's feet) just doesn't make good financial sense. After all, most investments may go up as well as down.

So we are considering getting into bed with our friendly neighbourhood purveyor of all things good. And why not? There are over a million people out there who have diabetes but don't yet know it, many of whom will not be seen in general practice until it's too late. They go to the supermarket though, don't they? Obviously they do, because it's their obesity and lack of activity that brings on the problem. So we'll be able to catch them there. Come to think of it, we could have one of those demonstration stands to attract people for blood sugar tests. Our new health care assistant could run this for us and perhaps it could be linked in with an offer of the week. Put it between the sweets and the ice cream and we'll be laughing. And what about those midnight shoppers who want to join the mile-aisle club? Being in a 24-hour store will mean emergency contraception is available 24 hours too so they can collect this as they leave on aisle one.

And men, they don't like going to the doctor's, do they? They don't like going to the supermarket either, but you often see them there. Single men wandering round aimlessly, looking like fish out of water, as they struggle to fit oven-ready meals and beer packs into a small basket. Attached men looking bored, wishing they could be doing something else, as their partner drags them from aisle to aisle. So here's an opportunity to make the supermarket visit exciting: a cardiovascular risk check. And let's not forget the women who don't have time for a pill check but who have time to fill two trolleys each week with special offers.

Being in the supermarket means I'll be first in line for those unbelievable deals my patients tell me about. The ones that are inevitably history by the time I get anywhere near the store. The multi-region DVD player

J Fam Plann Reprod Health Care 2006; 32(4): 261

Shopshire, UK

Tess Bootbury, MRCGP, General Practitioner for $£ 19.99$, for example, or the free 10-piece barbeque set with every family BBQ meal. It's beginning to sound like Christmas already, which is another bonus. I'll be able to do my Christmas shopping with ease rather than it being the annual last-minute rush that always ends in tears because 'the toy' has sold out. Even better, if I get friendly with the security staff the CCTV footage will keep me entertained and help me identify the person who anonymously leaves us those tins of disgusting Danish cookies every year.

General practice has always been the local health shop so there's no real change. Patients, or health shoppers as they'll now be called, will love it. In one swift supermarket sweep they'll be able to get their condoms, candles, luxury seduction food pack and a repeat prescription of the pill if they need to. For them it will be like 'double points bonus week'. This will, of course, be reflected in our patient satisfaction surveys so it will be bonus points for us too.

There will be loads of car parking, so no more arguing about verrucas not qualifying you to park in the disabled space. The in-store café-come-waiting-area will mean less risk of angry enquiries along the lines of "Why have I been waiting 30 minutes to see "im?" as the selection of cream cakes and coffee will lull them into a postprandial calmness never before seen in general practice. There'll be a much wider selection of magazines than we could ever provide, and they won't be so old with health advice that's been turned on its head: "Rubber condoms? Whatever will they come up with next?!".

Moreover, they won't get upset when they're told to buy paracetamol because it will be just around the next aisle. Well, I assume it will be. Knowing our luck we'll be squeezed in between the cigarettes and the booze. Now that would be an amusing irony since there's no other place a doctor would rather be. Put us next to the lottery machine and I'll have difficulty keeping a straight face. Lottery ticket? Do you want the national one or 'Choose and Book'?

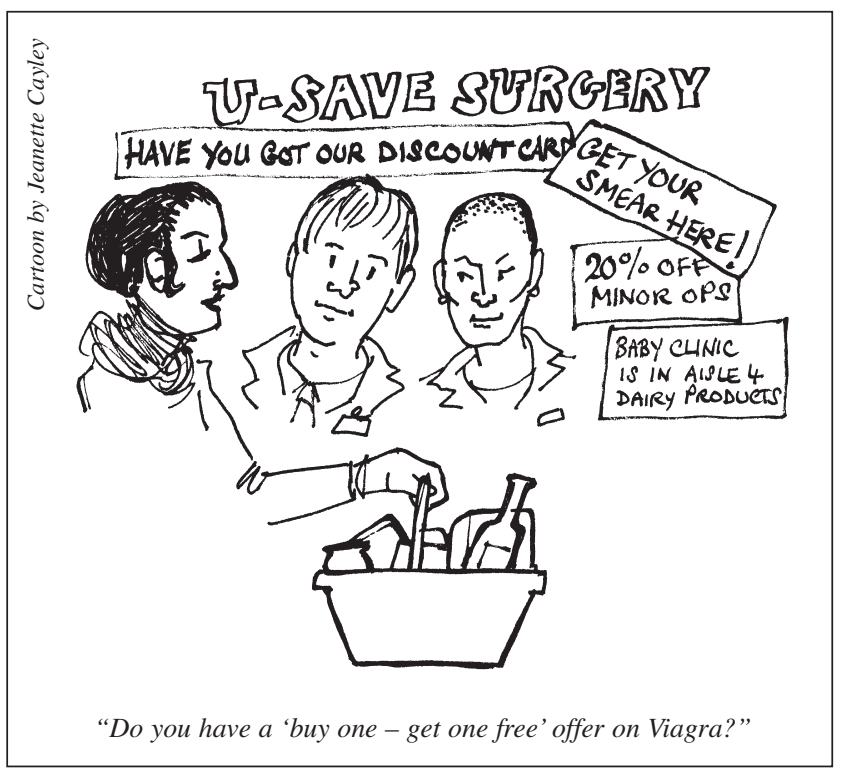

